\title{
INNOVATIVE ACTIVITY - THE BASIS OF ECONOMIC SUSTAINABILITY
}

\author{
Abdumuminov Axrorjon ${ }^{1}$ \\ ${ }^{I}$ Andijan Institute of Agriculture and agrotechnologies \\ E-mail: akhrorabdumuminov@gmail.com
}

\begin{abstract}
There is hardly anyone who has not heard of the concept of innovation, which is becoming an integral part of our lives. This is because the concept has had an impact on all sectors. As a result, the economy of our country is moving towards development. This is because innovation is a cost-effective process that is able to create new demands in the economy, more efficiently than existing ones, and help minimize costs. the role of entrepreneurship and small business, the future innovative plans of our country.

Key words: innovation, innovative activity, innovative environment, implementation of new combinations, Schumpeter, P. Druker, Global Innovation Development Index, invention, discovery and etc.

\section{Introduction}

In a market economy, it is clear that all developed countries achieve their high level of development as a result of scientific and technological advances in science and technology and their widespread implementation, especially in the effective implementation of production. In his Address to the Oliy Majlis, President of the Republic of Uzbekistan Shavkat Mirziyoyev called 2018 the "Year of Active Entrepreneurship, Support of Innovative Ideas and Technologies" in our country and said: "Today we are moving on the path of innovative development aimed at radical renewal of all spheres of life of the state and society.This is not in vain, of course. For in this fast-paced world, who will win? A state based on new ideas, new ideas and innovations will win."

This strategic task requires attention to such topical issues as the introduction of new forms and types of organization of innovative activities in the economy, the development of effective innovative projects, their development by attracting investment in entrepreneurship and business. In the current trend of scientific and technological development, increasing attention is paid to the development and promotion of innovative activities as one of the most favorable and effective factors of economic growth. Of course, modern development has no meaning and content without the intellectual product obtained as a result of innovative activity. The interconnectedness of science and economic life is expanding. The phrase "A strong science - $a$ strong economy" remains relevant not only for today, but also for the future of mankind.
\end{abstract}

\section{Main part}

It should be noted that for the past five years, an annual fair of innovative ideas, technologies and projects has been held. So, what is the main purpose of such projects in our country or to create a fully innovative environment?

The main goal is to create conditions for the growth of high-tech and high-tech production, as well as the formation of skills for the sustainable development of small innovative businesses, to solve current problems in the development of socio-economic spheres of the country,effective use of scientific and technical potential of research organizations, encouragement to increase investment and innovation activity of enterprises, especially small businesses, and attract investment in the expansion of innovative activities.

Accordingly, given the relevance of the chosen topic, it is important to study the content of the category "innovation" and its importance. In science, the word "innovation" is derived from the English word "innova", which means "making new things". At the heart of this is a new order, a new habit, a new method, a new discovery, a new vision and a new idea.

Innovation is the process of creating a new product and applying it in practice, expressing a new scientific and technical achievement. In the economic literature, the concept of "innovation" is interpreted as the process of creating real, new products and technologies of scientific and technical potential. The concept of innovation or "implementation of new combinations" includes the strategic advantages and achievements of the great economist Schumpeter through the continuous improvement of the organization, product or production process. In Schumpeter's view, the following five cases can be considered as innovations:

$>\quad$ preparation of new blessings;

$>\quad$ introduction of a new method of production;

$>\quad$ development of a new sales market;

$>\quad$ to have a new source of raw materials or semi-finished products;

$>\quad$ relevant reorganization, for example, to ensure a monopol 
Well-known researcher P. Druker also tries to substantiate the economic content of innovation and describes it as a unique tool that entrepreneurs can use to make changes, such as implementing new services or a type of business. P.Drucker's definition complements the essence of Y.Shumpeter's classical definition, and at the same time emphasizes the importance of the organizational and economic factor as a condition for effective development and the need to apply new products in practice. Many researchers focus on technological innovations, which are a direct description of the intensity of production development. These include production technologies, methods, tools and changes that determine the development of science and technology.

The essence of innovative activity is explained, firstly, by the introduction of new, improved production, secondly, by reducing all types of production costs, and thirdly, by constantly increasing their consumption and quality characteristics while reducing the cost of manufactured products.

Thus, science-based news becomes innovation from the moment it is disseminated and introduced. The process of introducing innovations to the market is called the process of commercialization of innovations. In our opinion, innovation is the introduction of a new or significantly improved product (product, service) or process, a new method of marketing, a new organizational style in work practice, workplace organization or external relations. Innovation is a materialized result of attracting capital to new equipment or technology, new forms of production organization, services, management, etc. The process of creating, mastering and disseminating innovations is understood as an innovative activity or innovation process.

The result of innovative activity can also be called an innovative product. Innovation is the end result of an innovative activity that reflects the creation of a new type or improved product for sale in the market, a new type or improved technological process used in practice. In addition, the term "innovation" is related to the concepts of "invention" and "discovery". Usually, "invention" means the creation of new tools, equipment and mechanisms by mankind that were previously unknown to science. The term "discovery" refers to the process of obtaining information or observing natural phenomena that were previously unknown to science.

The minimum sign of innovation is that the product, process, marketing or organizational style must be new (or significantly improved) for the practice of the organization, regardless of whether it was created or mastered by the firm. Innovative activity is all scientific, technological, organizational, financial, commercial, marketing activities that actually lead to the realization of innovation or are intended for this purpose. Innovative activity also includes research and development that is not directly related to the preparation of any particular innovation.

Admittedly, the role of innovation in our modern economy is growing day by day. It is impossible to create competitive products with a high level of knowledge and innovation without the use of innovation. Therefore, innovations in a market economy are an effective tool in competition, which leads to the emergence of new requirements, reduced production costs, increased investment flows, increased image and rating of new producers, the opening and capture of new domestic and foreign markets. In this regard, Uzbekistan plans to become one of the 50 most innovative economies in the world in 2030 - this task is reflected in the recently adopted and developed strategy of the country, in which UNDP participated.

As mentioned above, "the higher the level of innovation, the higher the GDP." Our country is a member of the Global Innovation Development Index to identify and analyze innovative development. The Global Innovation Index is a global study of the level of innovation development and a ranking of the world's leading countries. The index consists of 81 indicators that describe in detail the innovative development of countries in the world at different levels of economic development. The economic essence of innovation is to benefit from its results and use it as a source of financial resources.

\section{Conclusion}

In short, at present, the development of the economy in our country is accompanied by structural changes in all sectors. In particular, in the process of introducing innovations in production and services, many problems arise, and their timely solution requires the provision of the necessary personnel and material and technical base, as well as organizational and methodological measures, scientific researchs. The formation of an innovative environment is an important factor in creating opportunities for constant product renewal, renewal of production assets on the basis of new techniques, socio-economic development of the country. Adapting the innovation process to the environment of small business, increasing its efficiency requires full use of existing socio-economic opportunities. This is because the small business sector is the basis of the economy of any developed and developing country.

In a market economy, the innovative activity of small business is an effective tool for competition, leading to the emergence of new consumers, lower production costs, investment inflows, higher ratings of new producers, the opening and capture of new domestic and foreign markets. It is known from history that the innovative ideas that emerged in the field of small business today formed the basis of the world-famous McDonald's hamburgers, Apple computers, Ford car companies and others.

References:

1.Address of the President of the Republic of Uzbekistan Shavkat Mirziyoyev to the Oliy Majlis 
[22.12.2017]

2.Кирпичников М. «Наука как основа экономики». Доклад министра науки и технологий РФ. М 2016. Стр. 1.

3.Ковалёв Г.Д. Основы инновационного менеджмента. -М., 1999. - Стр. 192.

4.Шумпетер И. Теория экономического развития (исследование предпринимательской прибыли, капитала, кредита, процента и цикла конъюнктуры).-М.: Прогресс, 1982. - С. 159.

5.Ablaqulovich, I. G., Salaxuddinovna, K. Z., Uytalovich, N. U., \& Matlubovich, T. O. (2020). THE IMPACT OF THE ORGANIZATION OF A COTTON-TEXTILE CLUSTER ON THE SOCIO-ECONOMIC DEVELOPMENT OF THE REGIONS. International Engineering Journal For Research \& Development, 5(4), 5-5.

6.ugli Khurramov, A. M. (2020). The role and role of digital economy and information technology in the agricultural sector. International Journal on Integrated Education, 3(2), 42-44.

7.Ilkhomovich, S. E. (2020). The development of electronic trade and its role in general trade activities. ACADEMICIA: An International Multidisciplinary Research Journal, 10(3), 128-132. 